\title{
Incorporating Climate Change Impacts and Adaptation in Environmental Impact Assessments
}

\section{Opportunities and Challenges}

Shardul Agrawala, Arnoldo Matus Kramer, Guillaume Prudent-Richard and Marcus Sainsbury

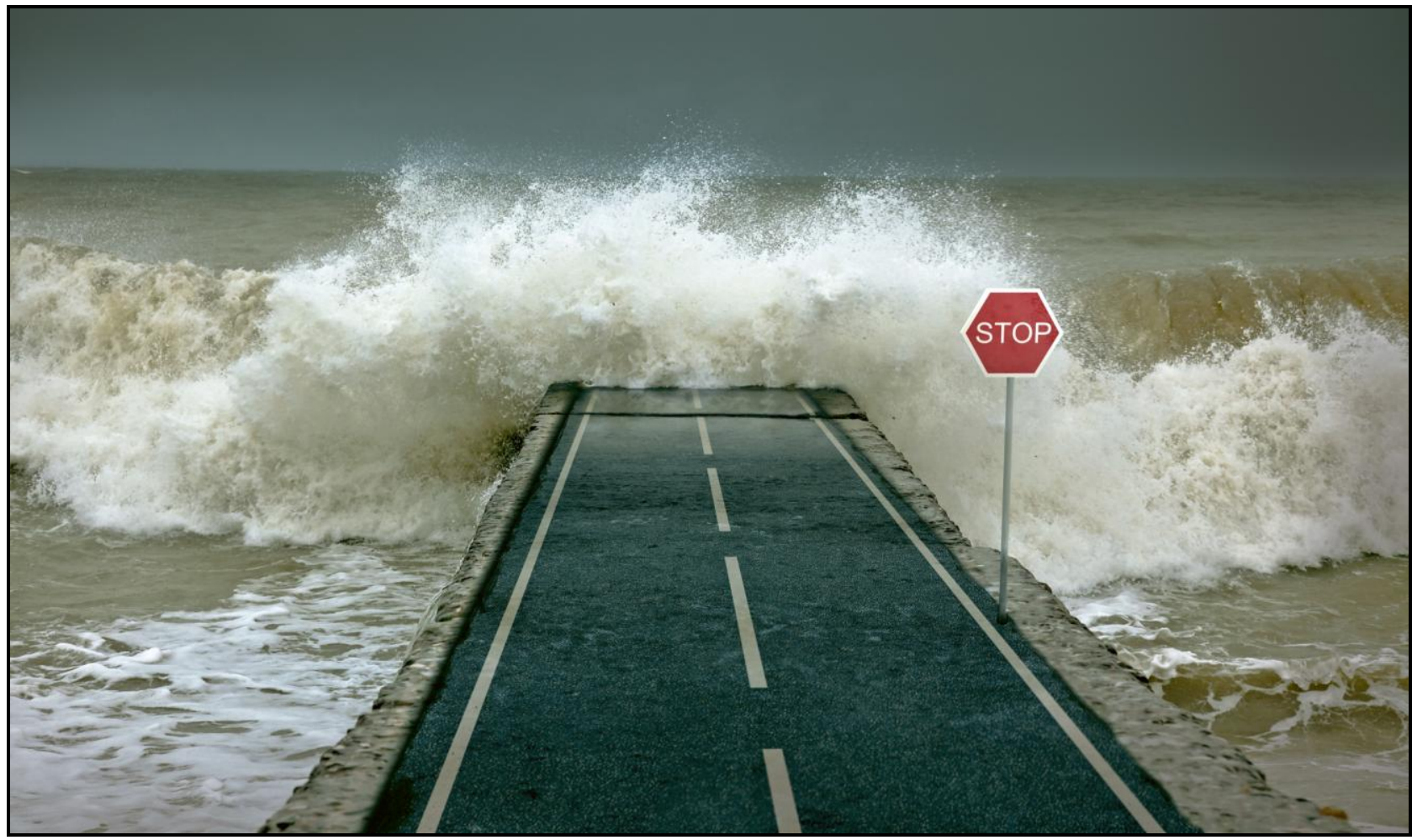

Photo ๔ Victor Zastolskiy - Fotolia.com

JEL Classification: Q51, Q54, Q58

Please cite this paper as:

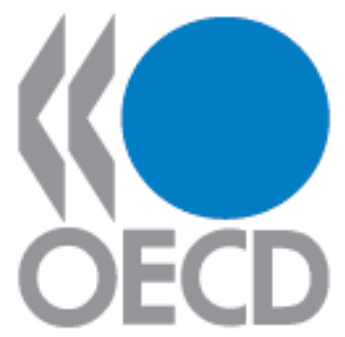

Agrawala S., A. Matus Kramer, G. Prudent-Richard and M. Sainsbury (2010), "Incorporating climate change impacts and adaptation in Environmental Impact Assessments: Opportunities and Challenges", OECD Environmental Working Paper No. 24, OECD Publishing, (C OECD. doi: $10.1787 / 5 \mathrm{~km} 959 \mathrm{r} 3 \mathrm{jcm}$-en 
Organisation de Coopération et de Développement Économiques

Organisation for Economic Co-operation and Development

29-Nov-2011

ENVIRONMENT DIRECTORATE

English - Or. English

Cancels \& replaces the same document of 17 August 2010

ENVIRONMENT WORKING PAPER NO. 24

INCORPORATING CLIMATE CHANGE IMPACTS AND ADAPTATION IN ENVIRONMENTAL IMPACT ASSESSMENTS: OPPORTUNITIES AND CHALLENGES

By Shardul Agrawala (1), Arnoldo Matus Kramer (1), Guillaume Prudent-Richard (2) and Marcus Sainsbury (2)

(1) OECD Environment Directorate

(2) AECOM, Australia

JEL Classification: Q51, Q54, Q58

Keywords: Environmental Impact Assessment (EIA), Climate Change, Adaptation, Risk Assessment

All Environment Working Papers are available at www.oecd.org/env/workingpapers

JT03312436

Document complet disponible sur OLIS dans son format d'origine

Complete document available on OLIS in its original format 


\section{OECD ENVIRONMENT WORKING PAPERS}

This series is designed to make available to a wider readership selected studies on environmental issues prepared for use within the OECD. Authorship is usually collective, but principal authors are named.

The papers are generally available only in their original language English or French with a summary in the other if available.

The opinions expressed in these papers are the sole responsibility of the author(s) and do not necessarily reflect those of the OECD or the governments of its member countries.

Comment on the series is welcome, and should be sent to either env.contact@oecd.org or the Environment Directorate, 2 rue André Pascal, 75775 PARIS CEDEX 16, France.

OECD Environment Working Papers are published on www.oecd.org/env/workingpapers

Applications for permission to reproduce or translate all or part of this material should be made to: OECD Publishing, rights@oecd.org or by fax 33145249930.

Copyright OECD 2010 
ENV/WKP(2010)10

\begin{abstract}
National governments and development agencies have invested considerable effort in recent years to develop methodologies and tools to screen their projects for the risks posed by climate change. However, these tools have largely been developed by the climate change community and their application within actual project settings remains quite limited. An alternate and complementary approach would be to examine the feasibility of incorporating consideration of climate change impacts and adaptation within existing modalities for project design, approval, and implementation. Environmental Impact Assessments (EIA) are particularly relevant in this context.

This analysis shows that there is ample scope for employing EIA procedures as a vehicle for enhancing the resilience of projects to the impacts of climate change. A number of entry points have been identified to incorporate climate change impact and adaptation considerations, from the strategic phase that precedes the initiation of the EIA, to the scoping, detailed assessment and implementation stages. Several national and sub-national authorities as well as multilateral development banks have already made some progress in terms of examining the possibility of incorporating climate change impacts and adaptation measures within the context of EIA modalities.

To a large extent, however, the goal of incorporating climate change impacts and adaptation within environmental assessments remains more aspirational than operational. While a number of governments have signalled their intent to move in this direction, this assessment could find examples in only three countries of projects that considered climate change impacts and adaptation as part of the EIA. A key bottleneck here is the availability of detailed information on the historical climate, as well as fairly specific scenarios of future climate for the project location. In many jurisdictions such information is currently not available. There is also the risk of unnecessary or even counterproductive investments in altering project design if the uncertainties associated with climate change projections are not adequately considered. While innovative approaches are currently being tested in various jurisdictions to incorporate climate change impacts and adaptation within EIA, it is important that they retain a certain degree of flexibility to accommodate better and more detailed climate change information as it becomes available. There is also a concomitant need to make substantial and long-term investments in the provision of climate change information, as well as establishing good communication mechanisms between the scientific community and practitioners.
\end{abstract}

JEL Classification: Q51, Q54, Q58

Keywords: Environmental Impact Assessment (EIA), Climate Change, Adaptation, Risk Assessment 


\section{RÉSUMÉ}

Les administrations nationales et les agences de développement ont consacré un effort considérable ces dernières années à la conception de méthodologies et d'outils d'évaluation de leurs projets du point de vue des risques posés par le changement climatique. Une bonne part de ces instruments ont toutefois été élaborés au sein de la communauté des spécialistes du climat mais sont encore rarement appliqués à des projets concrets. Une autre approche, complémentaire, serait d'étudier la faisabilité de la prise en compte des incidences du changement climatique et de l'adaptation à ce changement dans les modalités existantes de conception, d'approbation et de mise en œuvre des projets. Les études d'impact sur l'environnement (EIE) sont particulièrement intéressantes à cet égard.

Cette analyse montre qu'il existe de grandes possibilités d'utiliser les procédures d'EIE pour augmenter la résilience des projets aux effets du changement climatique. Un certain nombre de points d'entrée sont recensés pour intégrer des considérations relatives aux incidences du changement climatique et à l'adaptation, depuis la phase stratégique qui précède le lancement de l'EIE jusqu'aux étapes de l'étude exploratoire, de l'évaluation détaillée et de la mise en œuvre d'un projet. Plusieurs administrations nationales et infranationales ainsi que des banques multilatérales de développement ont déjà progressé dans l'examen de la possibilité d'intégrer dans les modalités des EIE les effets du changement climatique et les mesures d'adaptation.

Cependant, l'idée d'intégrer dans les évaluations environnementales les effets du changement climatique et l'adaptation à ce changement reste, dans une large mesure, un objectif qui relève davantage de l'ambition que de l'application concrète. Bien que plusieurs gouvernements aient manifesté l'intention d'agir, la présente évaluation a pu trouver dans trois pays seulement des exemples de projets tenant compte dans leur EIE des effets du changement climatique et de l'adaptation. Un obstacle clé tient à l'absence d'informations détaillées concernant l'évolution passée du climat ou de scénarios à peu près précis de l'évolution future sur le lieu d'implantation des projets. En ce qui concerne de nombreuses entités territoriales, on ne dispose pas aujourd'hui de données communément admises en la matière. Il existe en outre le risque d'engager des investissements non nécessaires, voire contreproductifs, pour modifier la conception d'un projet, s'il n'est pas tenu compte de façon appropriée des incertitudes liées aux projections de l'évolution du climat. Diverses entités territoriales testent actuellement des approches innovantes permettant de prendre en considération dans le cadre des EIE les effets du changement climatique et les actions d'adaptation, mais il importe qu'elles prévoient une certaine marge de manœuvre pour pouvoir ultérieurement faire place à des informations de meilleure qualité et plus détaillées sur le changement climatique, au fur et à mesure qu'elles deviendront disponibles. Il est dans le même temps nécessaire d'investir des montants considérables à long terme dans des moyens permettant de fournir des informations sur le changement climatique, ainsi que de créer des mécanismes efficaces de communication entre la communauté scientifique et les hommes de terrain.

Classification JEL: Q51, Q54, Q58

Mots clés : Étude d'impact sur l'environnement (EIE), Changement climatique, Adaptation, Évaluation des risques 


\section{FOREWORD}

This report on "Incorporating climate change impacts and adaptation in Environmental Impact Assessments (EIA): Opportunities and Challenges" is an output of the OECD Task Team on Climate Change that is overseen jointly by the Working Party on Global and Structural Policies of the Environment Policy Committee (EPOC) and the Network on Environment and Development Co-operation (Environet) of the Development Assistance Committee (DAC).

This report is authored by Shardul Agrawala, Arnoldo Matus Kramer, Guillaume PrudentRichard and Marcus Sainsbury. In addition to members of the OECD Task Team, the authors would like to thank Sameer Akbar, Adam Fearnley, Michael Nolan, Rob Verheem and Peter Wright for valuable information and feedback on environmental assessments. The authors also gratefully acknowledge comments and feedback from Cécile Bordier, Maëlis Carraro, Jan Corfee-Morlot, Elisa Lanzi, Helen Mountford, Remy Paris and Victoria Schreitter at the OECD.

This document has been produced with the financial assistance of the European Union.

This paper is released as part of the OECD Environment Working Papers series [ENV/WKP(2010)10]. It can be downloaded on the OECD website: www.oecd.org/env/workingpapers or www.oecd.org/env/cc/adaptation.

This document does not necessarily represent the views of either the OECD or its member countries. It is published under the responsibility of the authors.

Further enquiries on ongoing work on Adaptation to Climate Change should be directed to Shardul Agrawala, OECD Environment Directorate (Email: Shardul.Agrawala@oecd.org; Tel: +3314524 $1665)$. 


\section{TABLE OF CONTENTS}

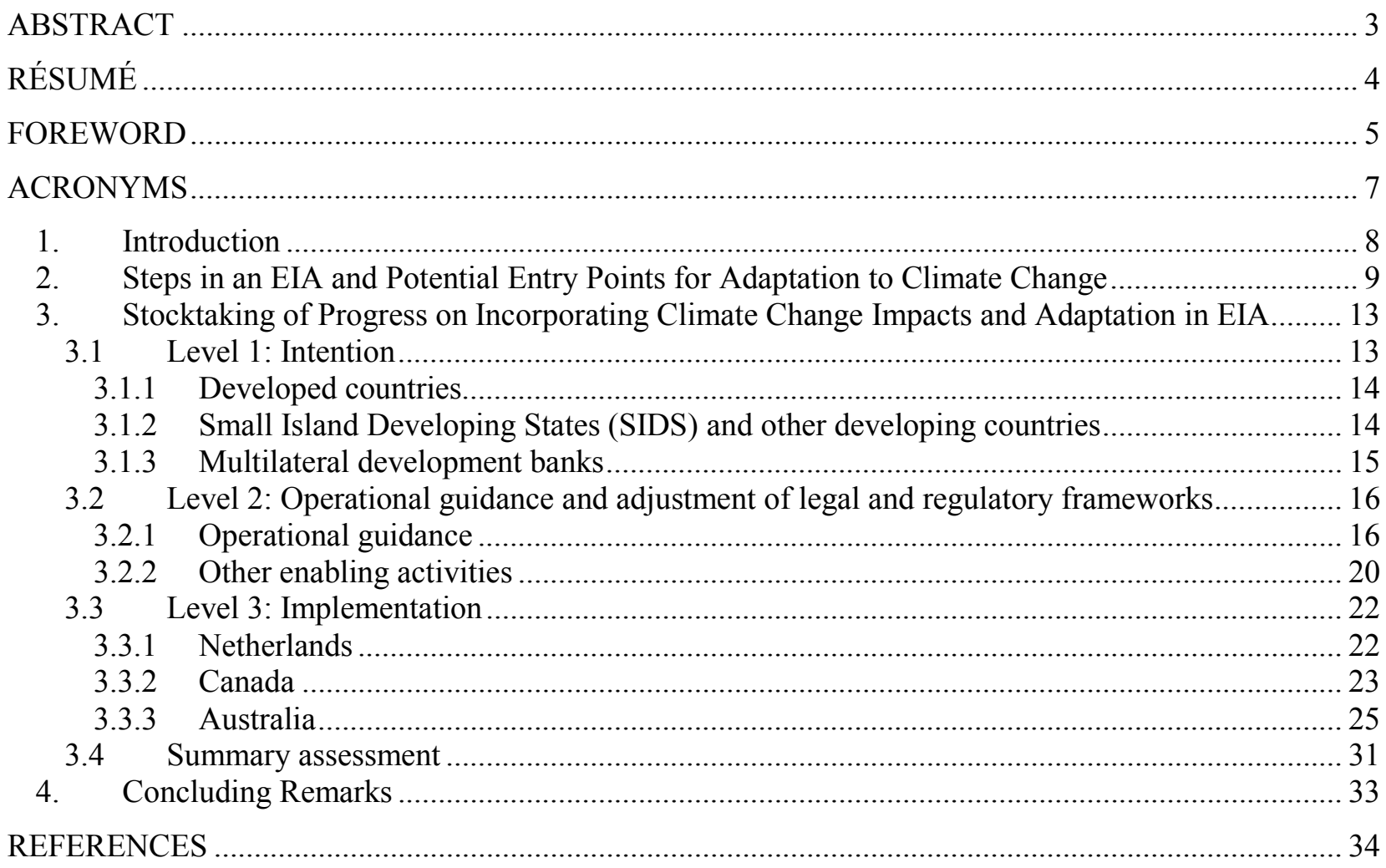

\section{Tables}

Table 1. Climate change considerations in the EIA of projects in Canada ...........................................2

Table 2. Example of Australian projects requiring consideration of climate change in an EIA.............26

\section{Figures}

Figure 1. Potential entry points for considering climate change impacts and adaptation in EIA............. 11

Figure 2. Floodway with 1 in 100 years flood level and $300 \mathrm{~mm}$ freeboard........................................2

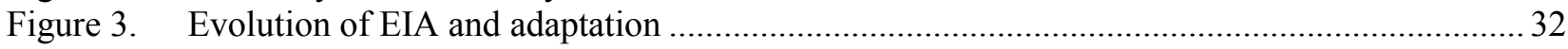

\section{Boxes}

Box 1. CEAA Guidance on incorporating climate change considerations in EIA ............................. 18

Box 2. CARICOM Guidance for incorporating climate change adaptation in the EIA ...................... 19

Box 3. Recommendations to integrate climate change adaptation in Jamaica's EIA.........................20

Box 4. Legal implications of climate change for planning and infrastructure ...................................22

Box 5. Using climate data and risk framework for EIA: Armidale landfill, Australia .......................229 
ENV/WKP(2010)10

\section{ACRONYMS}

ACT

ADB

CARICOM

$\mathrm{CDB}$

CEC

CEAA

CEMP

CSIRO

EA

EC

EIA

EMP

EU

IADB

IAIA

IEA

IPCC

GHG

LDCs

NAPA

NCEA

NSW

OECD

OEMP

SEA

SIDS

UNFCCC

WB
Australian Capital Territory

Asian Development Bank

Caribbean Community

Caribbean Development Bank

Certificate of Environmental Clearance

Canadian Environmental Assessment Agency

Construction Environmental Management Plan

Australian Commonwealth Scientific and Industrial Research Organisation

Environmental Assessment (sometimes used synonymously with EIA)

European Commission

Environmental Impact Assessment

Environmental Management Plan

European Union

Inter-American Development Bank

International Association for Impact Assessment

Institute of Environmental Assessment

Intergovernmental Panel on Climate Change

Greenhouse Gas

Least Developed Countries

National Adaptation Programme of Action

Netherlands Commission for Environmental Assessments

New South Wales

Organisation for Economic Co-operation and Development

Operation Environmental Management Plan

Strategic Environmental Assessment

Small Island Developing States

United Nations Framework Convention on Climate Change

World Bank 


\section{Introduction}

Climate change poses a serious challenge to economic development. The nature and type of development that occurs also has implications for greenhouse gas (GHG) emissions as well as the vulnerability of society to climate change impacts. Therefore, it has been widely recognised that there is a need to integrate consideration of climate change and its impacts in development policies and projects. The project level is particularly critical for the consideration of climate change risks and for incorporating suitable adaptation measures. Infrastructure projects, which are a crucial vehicle for economic development, could be particularly sensitive owing to their long lifetimes during which many impacts of climate change may become progressively more and more significant. A project may also affect the vulnerability of natural and human systems to climate change and could therefore lead to maladaptation. For all these reasons, there has been considerable effort by development co-operation agencies and national governments to develop methodologies and tools to screen projects for climate change risks. These tools, however, have largely been stand-alone initiatives and their application within actual project settings remains quite limited.

An alternate and complementary approach would be to examine the feasibility of incorporating considerations of climate change impacts and adaptation within existing modalities for project design, approval, and implementation. Environmental Impact Assessment (EIA) is particularly relevant in this context. EIA involves assessing the possible impacts, whether adverse or beneficial, that a proposed project (generally infrastructure related) may have on the environment. The purpose of EIA is to assess the impacts of a proposed project on the environment before deciding on whether or not to undertake the project, and to develop and apply measures to avoid or minimize those impacts as conditions of approval for the project. The International Association for Impact Assessment (IAIA) defines EIA as "the process of identifying, predicting, evaluating and mitigating the biophysical, social, and other relevant effects of development proposals prior to major decisions being taken and commitments made" (IAIA, 1999). As social awareness of environmental issues has grown, particularly in relation to impacts from environmental pollution, so has the need for better environmental management.

In response to this growing awareness, EIA was first introduced in the USA in 1969, and is now well-established as an important environmental decision-making tool. It is widely used around the world to determine the criteria and thresholds by which a project should be implemented and operated. This is done, for example, through the introduction of conditions of approval, which become important benchmarks in terms of both controlling development and having reference points by which performance or assumptions can be tested and reviewed.

EIA primarily identifies the impacts of a proposed project on the environment, rather than the impact of environmental change (including climate change) on the project itself. ${ }^{1}$ As such it can be argued that EIA might not be an appropriate vehicle to incorporate adaptation considerations. In some circumstances, however, impacts of climate change may have implications on the eventual environmental performance of a project. This could be the case for projects such as drainage systems and storage facilities for hazardous materials or wastes, where inadequate consideration of climate change impacts, such as sea level rise and changes in extreme weather events, during project design could lead to unexpected downstream environmental consequences.

In actual practice, however, EIA processes often go beyond this narrow framing and also consider the impact of environmental conditions (such as the risk of soil erosion) on the project. 
Even in cases where such specific linkages are not obvious, there may still be incentives to incorporate consideration of climate change and adaptation within EIA. One of the main reasons to look at EIA as a tool to facilitate the successful "climate proofing" ${ }^{2}$ of projects or to avoid maladaptation to climate change, is that EIA is a well consolidated and publicly accepted process in many countries and in bilateral and multilateral development co-operation agencies (Petts, 1999). Furthermore, the consideration of climate change issues through EIA might in turn improve the resilience of the project being assessed to natural climate variability and natural hazards. From an implementation perspective it may therefore be potentially more efficient and effective to broaden the scope of existing EIA modalities to include climate change and adaptation considerations, as opposed to establishing and implementing parallel procedures for screening projects for climate change risks. ${ }^{3}$ The key aspect for consideration in the context of EIA is to determine how and when climate change adaptation becomes triggered within an EIA process. Experience suggests that the earlier these considerations are made, the easier they can be incorporated into the project development process, and at the least financial cost.

It is important, however, to examine how viable it is to broaden the scope of EIA procedures to accommodate consideration of the risks posed by climate change, and what some of the constraints might be for doing so. The central question is to determine whether the project is climate sensitive and if climate proofing is required. Other key issues are whether the information available on future climate change and potential impacts is robust enough (particularly at the spatial scale of particular projects) to be meaningfully taken into account within EIA and how to deal with the uncertainties in climate change projections. For instance, when the modelling results differ in terms of direction of changes or when the quantitative range of possible climate evolution is wide, it might prove challenging to practically integrate climate projections into the design elements of the project. Additionally, there is a need for technical capacity to identify and use climate change information as part of the assessment process.

This paper will seek to address these key issues. The paper first provides an overview of the key steps in an EIA process and identifies potential entry points for incorporating information on climate change impacts. It then develops a framework to assess progress made by both developed and developing countries towards the incorporation of climate change impacts and adaptation consideration within EIA. These experiences are then used to identify opportunities and constraints in using EIA to avoid the exposure (proactive approach) or enhance the resilience (reactive approach) of projects to climate risks.

\section{Steps in an EIA and Potential Entry Points for Adaptation to Climate Change}

According to the IAIA and the Institute of Environmental Assessment (IEA), EIA should include the following objectives:

- "To ensure that environmental considerations are explicitly addressed and incorporated into the development decision making process;

2 The term "climate proofing", while frequently used, is technically a misnomer as no project or activity can truly be made climate proof. A more accurate term would instead be "enhancing the climate resilience" of a project or activity. However, for the purposes of this paper the term "climate proofing" has been used.

3 In addition to the project level that falls within the remit of EIA, a similar argument can be made for incorporating climate change adaptation considerations at a more strategic level within Strategic Environment Assessments (SEA). The OECD has already developed a Guidance Note on including climate change considerations within SEA (OECD, 2008). Some examples of incorporating adaptation within SEA are also highlighted in the OECD Policy Guidance on Integrating Adaptation in Development Co-operation (OECD, 2009). This paper focuses on EIA at the project level. 
- To anticipate and avoid, minimize or offset the adverse significant biophysical, social and other relevant effects of development proposals;

- To protect the productivity and capacity of natural systems and the ecological processes which maintain their functions; and

- To promote development that is sustainable and optimizes resource use and management opportunities" (IAIA, 1999).

The Canadian Environmental Assessment Agency (CEAA) (2009) notes that EIA should be conducted as early as possible in the planning and proposal stages of a project for the analysis to be valuable to decision makers and to incorporate measures to reduce projected adverse impacts into the proposed plans. This is generally in line with the requirements for Strategic Environmental Assessment (SEA) which has been defined as "a systematic process for evaluating the environmental consequences of proposed policy, plan or programme initiatives in order to ensure they are fully included and appropriately addressed at the earliest appropriate stage of decision-making on par with economic and social considerations" (Sadler and Verheem, 1996). SEA is often considered complementary to the more projectbased EIA. Using both EIA and SEA in conjunction would result in environmental assessments being conducted at all levels of decision-making, ranging from policy/plan/program formulation to project management, implementation, and ultimately operation and decommissioning.

Figure 1 describes the possible entry points for considering climate change impacts and adaptation within EIA procedures. Actual EIA processes tend to be more flexible and context specific than the linear procedures that have been outlined. There is considerable opportunity to incorporate consideration of climate change scenarios and adaptation measures in such processes. 
Figure 1. Potential entry points for considering climate change impacts and adaptation in EIA

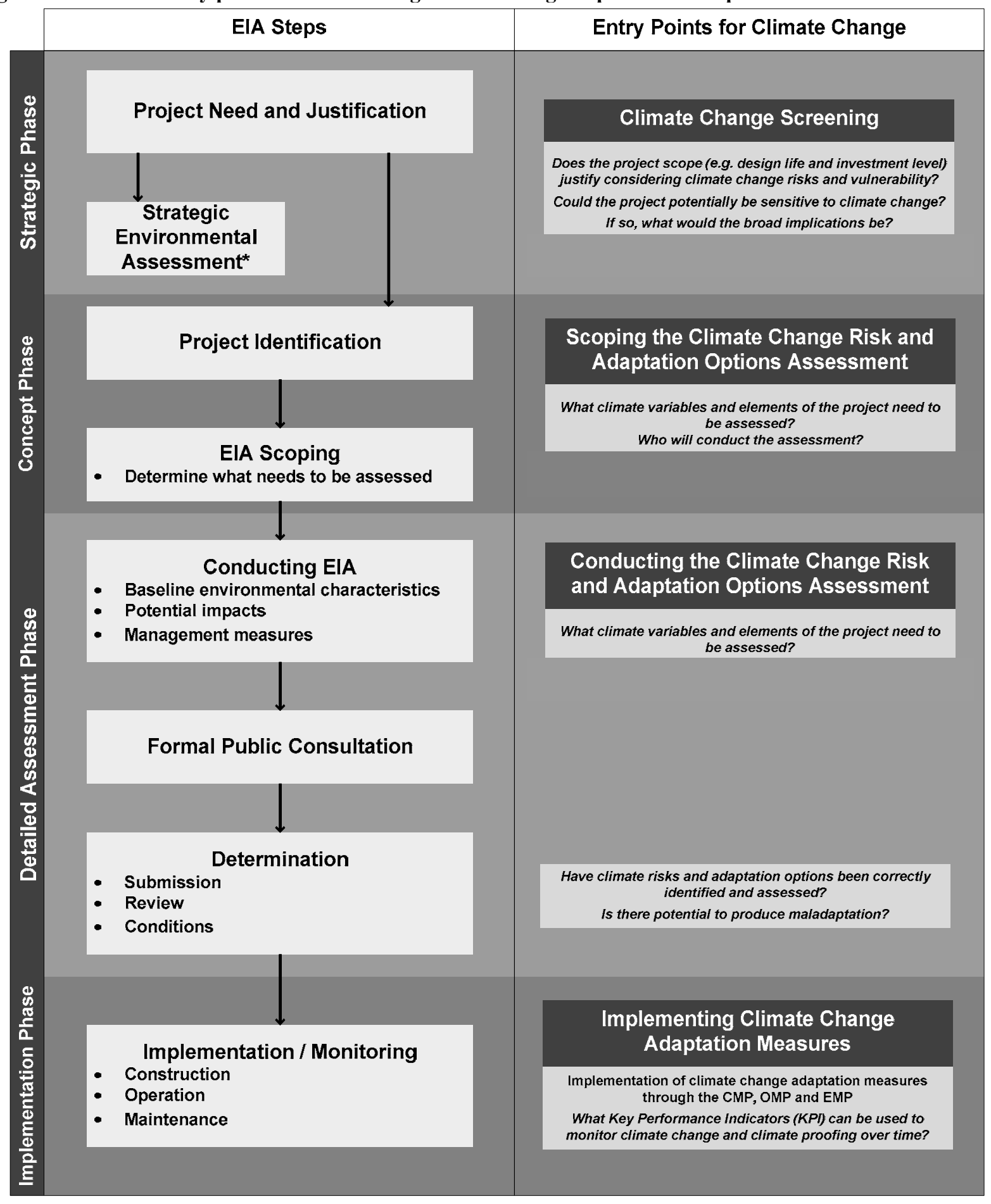

First, during a preliminary or strategic phase, the relevant authority screens the project for its need and justification. This phase should ideally include consideration of different alternatives within or to the project. At this stage it might be possible to also include a preliminary examination of whether the project scope (e.g. design life) justifies consideration of climate change risks and vulnerability. For example, if the project involves short term or temporary infrastructure or services, it may not be necessary to fully address those impacts of climate change that may become significant only over the long term. On 
the other hand, if it is a large scale project of medium longevity (e.g. 20 years design life for road pavements) or involves a long-lived asset (e.g. 100 years design life for a bridge) with a long term perspective, the impacts of climate change would almost certainly need to be considered.

Once it has been determined that an EIA is required at the project identification stage, the necessity of a full scale climate change risk assessment could be examined as part of the EIA scoping. The relevant authority should assess which climate variables and impacts might be relevant and would therefore need to be assessed for the project in question. These requirements should be communicated to the project developers who need to determine who should be engaged in the assessment process (authorities, experts and in some cases community stakeholders). This stage would also be a natural entry point for considering whether the climate risks associated with the project go beyond the project itself and potentially have feedback impacts on the environment or community.

Next, during the detailed assessment phase, the project proponent commissions a qualified practitioner with conducting the analysis and preparing an EIA report that identifies the potential impacts of the project on the environment and proposes measures to manage these potential impacts. An environmental baseline is established, against which the project's environmental performance can be evaluated. This environmental baseline is also used in compliance monitoring for the project during its operation and provides an opportunity to determine a baseline for the climatic variables of relevance to the project. This detailed assessment phase is a crucial entry point to consider the impacts of climate change on the project. As previously noted, suitable climate data needs to be available in order to consider relevant climate vulnerabilities for the given project. This would require sufficient expertise in climate change risk assessment, in order for the assessment to be meaningful and reliable. As with other aspects of an EIA, the quality and level of detail of the climate change assessment section would also be governed to a large extent by the resources devoted to this task.

The Caribbean Development Bank (CDB) and the Caribbean Community (CARICOM) suggest that, in order to consider climate change impacts, the EIA expert or advisory panel should be able to apply appropriate climate scenarios using a risk management approach. They also recommend criteria should be established so that the person conducting EIA criteria has the necessary expertise in natural hazards management and climate change. The same standard might be applied to government experts who review and assess EIAs (CDB and CARICOM, 2004). Such measures will ultimately serve to raise the standard of these assessments, and likely, by default, improve the outcomes from an environmental and climate proofing perspective. In this context, however, it should also be noted that conducting a detailed climate change risk assessment for a project involves undertaking assessment work which is largely additional to what has historically been undertaken for regular EIA. Accordingly, appropriate financial resources need to be provisioned to ensure that the assessments cover those issues which likely pose the greatest climate change risks to the project in sufficient detail, and result in an assessment of appropriate quality.

Following the detailed assessment, the EIA report is often formally presented to the public for comment and is submitted to the relevant regulatory authority for review. The same authority decides whether adverse environmental impacts are likely to be significant and unacceptable or whether the proposed project should proceed with or without adjustments and mitigation measures ${ }^{4}$. Both the public consultation and the EIA review can result in additional assessment work or clarification being required. This stage could also serve as an entry point to identify suitable measures to adapt to the impacts of climate change.

\footnotetext{
$4 \quad$ The term mitigation here refers to measures that reduce the impact of the project on the environment. Not to be
} confused with GHG mitigation. 
If a decision is made to implement the project, the measures identified in the EIA to reduce the risks posed by the project on the environment are incorporated into the design plans and implemented within the project, most typically through inclusion in the Environmental Management Plan (EMP). The EMP itself often involves preparation of a Construction Environmental Management Plan (CEMP) and an Operation Environmental Management Plan (OEMP). Any suitable measures to adapt to the impacts of climate change that have been identified in the previous stage could also be incorporated within these implementation plans.

Finally, as part of the approval conditions the implementation of mitigation measures often involves construction and operational audits to validate environmental performance. This monitoring could also be adopted for relevant climate change aspects identified as key risk elements. Such an approach would be useful to verify whether there is a follow-up of the EIA measures to reduce the anticipated impacts; however, this may prove difficult in the context of most infrastructure developments, given the often long timeframes associated with climate change. A robust climate risk assessment, however, might identify key indicators and thresholds, and adaptive management measures to be implemented at such thresholds. Indicators and thresholds could include climate variables (e.g. warming of air temperature by $2^{\circ} \mathrm{C}$ or sea level rise of $40 \mathrm{~cm}$ ) or any other information easy to collect and representative of the project climate vulnerability. Ongoing monitoring could therefore indicate if a project was approaching thresholds, and therefore dictate whether adaptive measures need to be triggered or developed.

\section{Stocktaking of Progress on Incorporating Climate Change Impacts and Adaptation in EIA}

Several national and sub-national authorities as well as regional organisations have already examined the possibility of incorporating climate change impacts and adaptation measures within the context of EIA modalities. The level of progress, however, varies considerably. This section provides a stocktaking of existing initiatives based on a three-level framework that starts with an analysis of broad trends and becomes progressively more specific. A distinction is made here between the articulation of broad intentions to move in this direction, enabling activities, and the actions themselves.

The first and broadest level examines the extent to which high level policy documents acknowledge the need to incorporate climate change impacts and adaptation considerations within EIA procedures. The second level of analysis examines the degree of progress made in various jurisdictions to translate the intentions articulated in the high level documents into operational guidelines to incorporate climate change impacts and adaptation in the EIA legal and regulatory framework. Finally, the third level of analysis examines instances of actual implementation where climate change was explicitly considered as part of the EIA process.

\subsection{Level 1: Intention}

Signalling the intention to integrate climate change considerations within EIA processes in development plans, climate change strategies and other relevant national and regional planning documents would ideally lead to a trickle-down effect to decision-making levels downstream where such intentions can eventually get translated into action. Multilateral organisations such as regional development banks can similarly influence the incorporation of climate change considerations within legal frameworks, or the development of operational guidelines at the national level.

This section documents available examples from developed countries, developing countries, as well as regional and multilateral bodies. In some cases, such as Canada, the emphasis is on a holistic approach to incorporate both GHG mitigation and climate change impacts/adaptation within environmental assessment processes. In other instances, particularly Small Island Developing States (SIDS), the focus is 
on incorporating climate change impacts/adaptation, as well as natural hazards management more generally within such processes.

\subsubsection{Developed countries}

Among the developed countries Canada is probably furthest along in terms of recognition of climate change considerations within the context of EIA. The incorporation of climate change impacts is a requirement of the EIA process for major development projects (Lee, 2001; Lemmen et al., 2008). This includes not only consideration of the impacts of climate change on the project, but also the implications of the project on GHG emissions. In 2003 the federal, provincial and territorial governments jointly released operational guidance for practitioners on how to incorporate climate change in EIA processes (Canadian Environmental Assessment Agency, 2003). There are also a number of examples in Canada where projects have sought to incorporate the impacts of climate change within the EIA, as well as an evaluation of how well these procedures are working. These elements are detailed in subsequent sections.

The European Commission (EC) has also proposed a revision of its EIA Directive to ensure that projects falling under this scope require climate proofing as a pre-condition. The Commission states that it will work with member countries and stakeholders to develop guidelines and exchange good practice, to ensure that climate change impacts are taken into account when EIA is implemented. The EC plans to develop guidelines by 2011 to ensure that climate impacts are taken into account in the EIA Directive (European Commission, 2009b). At the same time however, the EC (2009a) reports that the majority of European Union (EU) member countries rarely recognise climate change impacts in their EIA requirements. It highlights that one of the reasons could be the lack of proper tools and methodologies to carry out such assessments. Consequently, it recommends the development of guidance and assessment tools on the integration of climate change, particularly for climate-sensitive projects (European Commission, 2009a).

Some EU countries have also stated their need to integrate EIA in relevant national planning documents. This is, for example, the case of the Spanish National Climate Change Adaptation Plan (2006), which proposes the development of guidelines and regulations to incorporate climate change impacts into the EIA process, particularly, for projects in the water sector (Oficina Española de Cambio Climático, 2006). In fact, the Ministry of Environment of Spain considers EIA as an entry point to integrate adaptation to climate change across sectors since the Ministry can use its current legal mandate to do this (Oficina Española de Cambio Climático, 2009). In the case of the Netherlands, the Netherlands Commission for Environmental Assessment (NCEA) is providing technical advice to the government on climate proofing spatial development. Further detail on the activities of the NCEA is provided in the following section.

In Australia, at the national level, EIA provisions are contained within the Environment Protection and Biodiversity Conservation Act 1999 (EPBC Act). At the state and territory level, each jurisdiction has EIA provisions typically contained in land use planning law or in specific EIA legislation. Overlap between federal and state/territory requirements is addressed via bilateral agreements or one-off accreditation of state/territory processes, as provided for in the EPBC Act. Whilst strictly speaking a specific mandate within relevant legislation to consider climate change adaptation is not currently present, there is certainly an intent, supported by relevant guidelines and expressed by various levels of government to address climate change through what is seen as perhaps the most appropriate framework of EIA. Specific project examples illustrating the above are discussed later in this report.

\subsubsection{Small Island Developing States (SIDS) and other developing countries}

Among the developing countries, the SIDS have shown particular interest in the use of EIA as a tool to incorporate considerations of climate change in projects. A key motivation for this has been the 
high exposure of many of these countries to extreme climatic events, and the possibility that many of these hazards could be exacerbated by sea-level rise and increases in the intensity or frequency of tropical cyclones. In fact, some SIDS already recognise the need to use EIA as a tool to adapt to climate change in their National Communications to the United Nations Framework Convention on Climate Change (UNFCCC) and/or National Adaptation Programmes of Action (NAPA).

Samoa's National Communication recognizes the importance of using EIA to promote adaptation in development plans and protect biodiversity to climate change (Government of Samoa, 1999). Samoa's NAPA, meanwhile, emphasizes the mainstreaming of NAPA activities in existing legislation supporting sustainable development including EIA: "For instance, climate change factors are increasingly being assessed against development proposals in EA and EIA regulations formulation process [...]" (Government of Samoa, 2005). Kiribati's NAPA highlights that adaptation strategies for coastal zone management notably relate to the need to carry out EIA on any coastal development (Government of Kiribati, 2007). Kiribati already considers the integration of climate change adaptation in EIA processes (Environmental (General) Regulations, 2007, Section 33(1) (d) of the Environment Act). The scope for a basic EIA makes explicit reference to climate change and requires "a description of how climate change and climate variability may impact on the activity" (World Bank, 2009). The NAPA of the Solomon Islands notes that all development infrastructure projects require an EIA but that climate change related risks are not specifically taken into account as part of this process. This NAPA identifies EIA as one of the entry points for adaptation for the development and building of additional tailing ponds and dams for the mining sector (Government of Solomon Islands, 2008). Vanuatu's NAPA identifies the use of EIA as a way to mainstream climate change considerations in infrastructure design and planning as a priority adaptation. However, this aspect was considered to be covered in the Pacific Adaptation to Climate Change project and was consequently dropped from the NAPA list of adaptation priorities (Government of the Republic of Vanuatu, 2007).

The National Communication of the Cook Islands, meanwhile, argues that the current coastal vulnerability to climate change is exacerbated by "the lack of an effective EIA process as well as a fully integrated environmental management program" (Government of the Cook Islands, 2000). Dominica's National Communication states that measures should be taken to ensure that climate change considerations are integrated into the EIA process. Furthermore, it states that this should be adopted in conjunction with hazard mapping and risk assessment to define the extent of impact prone areas, and that comprehensive hazard information should become available for use by private, commercial and industrial developers to inform strategies for sustainable land use and economic development (Government of the Commonwealth of Dominica, 2001). Meanwhile, St. Lucia's National Communication states that it will upgrade EIA legislation to consider climate change considerations (Government of Saint Lucia, 2001).

Among the Least Developed Countries (LDCs), Bangladesh's National Water Management Plan Project (Government of the People's Republic of Bangladesh, 2005b), recommends the inclusion of climate change considerations into the EIA process, in particular, in the development of baselines describing the environment (Government of the People's Republic of Bangladesh, 2005b). However, this document does not provide any further guidance on how to do this. Meanwhile, Bangladesh's NAPA (Government of the People's Republic of Bangladesh, 2005a) recognizes that climate change issues are not adequately considered during the design of water resources structures. In fact, this document notes that the lack of proper assessment of climate change in designing and implementing structures make structural interventions more prone to climatic hazards (Government of the People's Republic of Bangladesh, 2005b).

\subsubsection{Multilateral development banks}

At a regional level, the Caribbean Development Bank (CDB) and CARICOM (2004) have also moved forward and proposed that member countries of the CARICOM should consider the impacts of 
environmental change on projects in the EIA process. They provide some recommendations and guidelines related to how CARICOM member countries could proceed to integrate climate change impacts.

The main recommendations provided by CDB and CARICOM include:

1. Establishment of formal EIA procedures to take into account environmental impacts;

2. Provision of clear criteria for screening and scoping environmental impacts;

3. Provision of clear EIA guidelines for the preparation of EIA reports;

4. Provision of clear criteria governing EIA experts (CARICOM, 2004; CDB and CARICOM, 2004).

The World Bank (WB), the Asian Development Bank (ADB) and the Inter-American Development Bank (IADB) have also identified the need to integrate EIA as a tool to climate proof their projects and infrastructure development activities (World Bank, 1999; ADB, 2005; IADB, 2008). For example, ADB states that for infrastructure projects it is possible to avoid most of the damage costs attributable to climate change if climate proofing is undertaken at the design stage of the project. Cost effectiveness can be further enhanced if EIA and related procedures require the climate proofing of all development projects (ADB, 2005).

\subsection{Level 2: Operational guidance and adjustment of legal and regulatory frameworks}

While calls for using EIA to promote adaptation or climate proofing in high level planning documents are clearly critical, they would need to be accompanied by suitable changes in the enabling environment to bridge the gap between intentions and action. This Level 2 analysis looks at the transition from high level intentions to the actual development of operational guidance and adjustments of legal and regulatory frameworks.

The analysis shows that relatively few countries, notably Australia, Canada, Guyana, Jamaica, Kiribati, the Netherlands and Trinidad and Tobago, have actually moved towards operational guidelines and/or adjusting regulatory frameworks to incorporate adaptation to climate change within EIA procedures.

\subsubsection{Operational guidance}

This assessment could identify only two examples - Canada and the CARICOM - of detailed operational guidance on incorporating consideration of climate change impacts and adaptation within EIA procedures.

Canada requires the assessment of climate change impacts for major development projects (Lemmen et al., 2008). The Canadian Federal Government provides guidelines on how to do this through the Canadian Environmental Assessment Agency (CEAA) (2003) Incorporating Climate Change Considerations in Environmental Assessment: General Guidance for Practitioners.

The CEAA provides general guidance to incorporate adaptation and mitigation to climate change and is applicable across jurisdictions. It includes the following main elements:

- "Methods that can be used to obtain and evaluate information concerning a project's GHG emissions and the impacts of climate change on a project; 
- Key sources of information that practitioners can use to address climate change considerations in project environmental assessments; and

- Methodology to encourage the consistent consideration of climate change in the environmental assessment process across federal, provincial and territorial jurisdictions and institutions of public government responsible for environmental assessments" (CEAA, 2003).

CEAA recognizes that the assessment of potential climate change impacts and the identification of effective adaptation responses are new and evolving fields in which more research is required. It states that: "While our understanding and policies are advancing, it is still useful that project proponents and government environmental assessment practitioners and decision makers be aware of any important climate change implications related to proposed projects. This guidance will evolve as climate change related science, and broader policy and action evolve."

The Canadian guidance proposes that when the risks of climate change impacts are associated with the private sector only, the project proponent can choose to absorb this risk. However, climate change related risks that go beyond the project itself to potentially affect the public or the environment, have to be factored into an informed decision by relevant authorities. It identifies as a priority, projects that are both located in climate sensitive areas and are identified as sensitive to the effects of changing climatic parameters (CEAA, 2003).

Box 1 summarizes the recommended procedures for addressing climate change impacts developed by the CEAA. Each of the steps proposed can easily mark entry points in the generic steps of a traditional EIA process. It follows the same structure of steps identified previously in Figure 1 of this paper. 
Box 1. CEAA Guidance on incorporating climate change considerations in EIA

\section{Step 1 - Preliminary Scope for Impacts Considerations}

- Focus on general considerations and readily accessible information;

- Are there likely impacts considerations associated with the project that should be addressed in greater detail?

- Document a rationale as to why, or why not;

- If there are no likely impacts considerations that should be addressed in greater detail, no further analysis is required;

- Proceed to Step 2 if further analysis is required;

\section{Step 2 - Identify Impacts Considerations}

- Identify project sensitivity to possible changing climatic parameters;

- Conduct more detailed collection of regional climate change and project specific information;

- Clarify changing climatic parameters (magnitude, distribution and rate of changes);

\section{Step 3 - Assess Impacts Considerations}

- Assess range of possible changes to climatic parameters;

- Determine the range and extent of possible impacts on the project;

- Assess the potential risks to the public or environment;

- Based upon the risks to the public or environment resulting from the effects of climate change on the project, determine whether impact management is required;

- If no further action is required, document impact analysis. No impact management required;

- Proceed to Step 4 if further action is required;

\section{Step 4 - Impacts Management Plans}

If the project is likely to pose risks to the public or environment resulting from the effects of climate change:

- Clarify mitigation measures to reduce project vulnerability;

- Clarify adaptive management plan to reduce risks associated with climate change;

- Incorporate ongoing information gathering and risk-assessment;

- Distinguish between public and private sector risks and responsibilities;

\section{Step 5 - Monitoring, Follow-Up and Adaptive Management}

If the project is likely to pose risks to the public or environment resulting from the effects of climate change:

- Monitor status of project and effectiveness of mitigation measures;

- Implement remedial action as necessary;

- Incorporate "lessons learned" into normal procedures;

- Address evolving project and climate change knowledge, technology, policy and legislation.

Source: Canadian Environmental Assessment Agency (2003)

Like the case of Canada, CARICOM has also developed operational guidance for EIA practitioners on how to incorporate climate change considerations. Box 2 presents a brief summary of these guidelines. Note that, as in the case of the Canadian guidance, each of the steps mark potential entry points for climate change considerations. In fact, there are close similarities between the Canadian and CARICOM guidance. This may be partly explained by the fact that the CARICOM guidance was developed with technical and financial assistance from Canada. 
Box 2. CARICOM Guidance for incorporating climate change adaptation in the EIA

\section{Step 1 - Define Project and Alternatives}

- Clearly describe proposed project, identify alternatives to project and to approaches to implementation;

\section{Step 2 - Preliminary Vulnerability Assessment}

- Preliminary identification of significant hazards and hazard impacts to inform EIA screening and scoping;

Process:

- Using existing information and expert knowledge, estimate frequency or probability of hazard events;

- Estimate severity of impacts on project components and zone of influence;

\section{Step 3 - Initial Screening}

- Determine, based on information provided, whether a) the project is likely to have a significant effect on the environment and b) climate change impacts are likely to have significant effects on the project, and therefore require further study;

\section{Step 4 - Scoping}

- Identify and agree upon the critical issues to be addressed in the EIA and the information and analyses required for inclusion in the environmental assessment report to determine acceptability and feasibility of the project;

Information needs:

- Baseline data on project site, existing detailed hazard maps and assessment;

- Significant hazards and potential impacts on project and zone of influence/ project boundaries identified in screening;

- Relevant legislation and institutions;

- Climate change assessments;

\section{Step 5 - Assessment and Evaluation}

- Fully assess and characterise significant natural hazards, their potential impact on the project and potential effects on those hazards introduced by the project;

Information needs:

- Baseline data, hazard studies and maps indicating past incidence, factors influencing hazard occurrence and climate change scenarios;

\section{Step 6 - Environmental Management Plan}

- A Climate Change Adaptation Program should be developed as part of the EIA process to address significant impacts from climate change that will affect the project and define adaptation measures that will be established to address climate change impacts.

CARICOM, together with CDB, have also developed some recommendations and guidance on how to integrate natural hazards management into EIA. Box 3 presents, as an example, the recommendations suggested for Jamaica. 
Box 3. Recommendations to integrate climate change adaptation in Jamaica's EIA

It is recommended that the following measures be implemented to support the integration of natural hazard mitigation and climate change adaptation considerations into the EIA process in Jamaica:

\section{(a) Revision of Definition of EIA}

It is recommended that the definition of EIA under the Natural Resources Conservation Authority Guidelines for Conducting Environmental Impact Assessments, 1998 be revised to also address the impacts of the environment (i.e. natural hazards and climate change) on the project.

(b) Provision of Clear Criteria for Screening and Scoping Environmental Impacts

It is recommended that procedures established under the Natural Resources Conservation Authority Guidelines for Conducting Environmental Impact Assessments, 1998 provide clear criteria for screening and scoping to ensure identification of the significant natural hazard impacts on the proposed project or activity. The development of such checklists can assist with the review and evaluation of the EIA report.

\section{(c) Provision of Clear EIA Guidelines for the Preparation of EIA Reports}

It is recommended that procedures established under the Natural Resources Conservation Authority Guidelines for Conducting Environmental Impact Assessments, 1998 ensure that the EIA process addresses natural hazard impacts. The provision of Model Terms of Reference for addressing natural hazard mitigation and climate change adaptation considerations would also assist applicants undertaking an EIA, and ensure consistency in approach.

\section{(d) Provision of Clear Criteria Governing EIA Experts}

It is recommended that the criteria be established under the Natural Resources Conservation Authority.

Guidelines for Conducting Environmental Impact Assessments, 1998 governing the qualification, skills, knowledge and experience which persons conducting EIA must possess, be reviewed to ensure that persons conducting EIA and assessing natural hazard impacts possess the requisite qualification, skills, knowledge and experience on natural hazards, hazard mitigation, climate change and climate change adaptation policies and measures. The same standard will have to be applied to government experts who review and assess EIA.

Source: CDB and CARICOM (2004)

In addition to the two examples mentioned above, EuropeAid (2009) has released comprehensive guidelines on the integration of environment and climate change in development cooperation. One chapter deals with the project perspective and suggests linkages between environmental risks and EIA. The specific entry points into the EIA process are, however, not the focus of these guidelines, and instead a more general way of incorporating climate change - even for projects not suitable for EIA - is described.

\subsubsection{Other enabling activities}

While this review was not able to identify other examples of detailed operational guidance on incorporating climate change impacts and adaptation considerations, there are nevertheless some related initiatives in other jurisdictions that aim to achieve similar objectives. For example, the Netherlands Commission for Environmental Assessments (NCEA) is a private foundation that provides advice to the Dutch government on this subject. NCEA has the objective to climate-proof spatial development using two main guiding principles: i) risk management which includes dealing strategically with uncertainty and damage mitigation; ii) natural processes which refers to the use of the properties of natural systems and giving these systems space (Draaijers and van der Velden, 2009).

Consequently, the NCEA investigates if adaptation to climate change should be considered in projects. For this, it takes into account the following: 
- Local climate impacts in the long and short-term;

- Nature of the area in which the adaptation must take place;

- Estimate of the risks;

- The additional short-term costs related to the costs avoided in the longer term: i.e. costs that increase as a result of management and maintenance, costs of later compulsory modifications, and costs incurred because there is now no room for other functions (Draaijers and van der Velden, 2009).

The NCEA also provides some recommendations on how to deal with climate change in EIA (Draaijers and van der Velden, 2009). The NCEA notes: "If adaptation is deemed to be a factor of significance, the NCEA requires information to be given on how the initiative can best respond to the impacts of climate change: how the risk of damage can be limited, and at the same time how the quality of life, the spatial quality and the safety can be maintained or enhanced. We also require information to be given about whether the project might hamper necessary adaptation measures in the future, for example by taking up space and thereby making it no longer possible to store water. It is also important to know whether the project might aggravate the consequences of climate change" (Draaijers and van der Velden, 2009).

In the context of developing countries, CARICOM (2004) reports that Grenada, and Trinidad and Tobago have some degree of formal integration of the impacts of climate change in their EIA legal frameworks. In Grenada, the EIA review committee uses the relevant information related to climate change impacts for specific projects when making a determination on EIA proposals (CARICOM, 2004). In Trinidad and Tobago, the EIA process forms part of the Certificate of Environmental Clearance (CEC) system. Its objective is to achieve integrated environmental management at the national level. This includes the assessment of proposed activities to consider likely impacts, environmental risks, as well as mitigation and monitoring for potential adverse effects. EIA is part of the CEC process and is undertaken to identify and evaluate specific environmental concerns of a proposed activity (CARICOM, 2004).

Recently, in New South Wales (NSW), Australia, a court case argued that an approval for a coastal development was invalid, on the grounds that the approving authorities had failed to consider whether existing flood risk in the area would be aggravated by climate change, see Box 4 . This ruling was later challenged in a higher court, where the decision was overturned. However, an important legal decision had been made which has subsequently influenced the scope and detail of EIA in NSW generally. 


\section{Box 4. Legal implications of climate change for planning and infrastructure}

In 2007, a court case was brought before the NSW Land and Environment Court (Walker versus the Minister for Planning and Ors, Walker Case). The Walker case related to a proposed development at Sandon Point on the southern NSW coast, near the city of Wollongong. The proponent of this project (Stockland Development and Anglican Retirement Villages) sought concept plan approval for approximately 180 residential dwellings, three super lots for future apartment or townhouse development, 200 to 250 senior living units and a residential aged care facility. The proposed site for development was known to be highly flood prone.

Whilst the EIA prepared for the project included specialist reports on flooding risk, none of these reports specifically considered whether the flood risk would be exacerbated by climate change. As such the Court found that "Climate change presents a risk to the survival of the human race and other species. Consequently it is a deadly serious issue. It has been increasingly under public scrutiny for some years. No doubt that is because of global scientific support for the existence and risks of climate change and its anthropogenic causes. Climate change flood risk is, prima facie, a risk that is potentially relevant to a flood constrained, coastal plain development such as the subject project" and failure to consider these issues rendered the decision to approve the concept plan invalid.

This ruling was later challenged in a higher court, where the decision was overturned; however, an important legal decision had been made which has subsequently influenced the scope and detail of EIA in NSW generally.

Source: Rudock (2009)

In 2009, the NSW Department of Environment, Climate Change and Water released a sea level rise policy statement, which sets out projections of sea level rise along the NSW coast relative to 1990 levels of $40 \mathrm{~cm}$ by 2050 and $90 \mathrm{~cm}$ by 2100 (New South Wales Government, 2009). This policy statement is referred to as a guidance document in the list of criteria drafted by the NSW Department of Planning for EIA requirements for some coastal projects. Coupled with provisions under the relevant Environmental Planning and Assessment Act 1979 for consent authorities to consider coastal and flooding hazards in their planning and development approval decisions, this effectively implies that EIA prepared for developments at risk of these hazards will need to present the potential risks posed by sea level rise and identify appropriate adaptation or response strategies before they can be approved.

\subsection{Level 3: Implementation}

As the previous sections show, there are very few countries that have already some level of integration of climate change adaptation in their EIA legal framework. Moreover, the existing operational guidelines have only been in place for a few years. One can conclude that this is reflected in the few examples of projects that have used EIA to address climate change impacts and are already documented. This research could only identify documented experiences of EIA helping to climate proof projects in three countries: Netherlands, Canada and Australia. It should be noted that there are examples where climate change adaptation has been considered without existing guidelines.

\subsubsection{Netherlands}

In the Netherlands, the plan 'Room for Rivers' aims to define the necessary measures to protect the Netherlands against flooding of the river Rhine in the coming decades, while incorporating climate change scenarios. This plan introduces a combination of measures from dike improvement or heightening; to creating more space for water discharge or retention in the river foreland or river bed (for example, through the removal of obstacles, deepening of the riverbed, creation of retention ponds, and relocation of dikes). This plan uses the SEA approach for its implementation. EIA is used as well for the more detailed design and implementation of the 40 projects which are part of the plan (Dutch Ministry of Transport, Public Works and Water Management, 2006; Verheem and Laeven, 2009). Climate change considerations were integrated when considering the high water levels to be expected for 2020 and possible developments in the upstream sections of the river in other countries, for example in Germany. For the year 2100 the 
water levels in the Rhine were calculated on the basis of the medium scenario of the Intergovernmental Panel on Climate Change (IPCC) that considers a $60 \mathrm{~cm}$ sea-level rise (Verheem and Laeven, 2009). Further details on the projects that take climate change impacts into account as part of the EIA are not publicly available.

\subsubsection{Canada}

Canada, as noted earlier, has several years of experience with integrating climate change impacts within EIA. There are examples of a number of projects including water-retention or tailings-containment structures, bridges, as well as large buildings and linear infrastructure such as pipelines and roads, which have used EIA to address climate change impacts in their design phase. Considerable detail is publicly available on many of these projects. Further, the experiences with incorporating climate change impacts within some of these projects have also been formally reviewed (Lee, 2001; Canadian Environmental Assessment Agency, 2003). These experiences provide important insights for this discussion and are therefore discussed in some detail below.

Lee (2001) reviewed six Canadian projects that included climate change considerations in the EIA design, planning, operation and, in one case, decommissioning. These projects were also selected because they could have longer-term environmental impacts. They include: the Cascade Power Park, the Confederation Bridge, Diavik mines, dredging in the St. Laurence River, the Little Bow reservoir, and decommissioning of Quirke and Panel mines. Table 1 provides a summary of climate change considerations in these projects and further details of some of these projects are discussed below.

Table 1. Climate change considerations in the EIA of projects in Canada

\begin{tabular}{|c|c|}
\hline Project & Climate Change Considerations \\
\hline Cascade Power Park & $\begin{array}{l}\text { Changes in hydroelectric regime potentially affecting } \\
\text { viability of operations and fisheries. }\end{array}$ \\
\hline Confederation Bridge & $\begin{array}{l}\text { Integrity of bridge structure over design life of project due } \\
\text { to a rise of } 1 \mathrm{~m} \text { in sea level, ice-out and inundation of low- } \\
\text { lying areas near the bridge. }\end{array}$ \\
\hline Diavik Mines & $\begin{array}{l}\text { Permafrost, integrity and design of facilities in light of } \\
\text { changes in air temperature, snow cover and precipitation } \\
\text { regime. }\end{array}$ \\
\hline Dredging of St. Lawrence River & $\begin{array}{l}\text { Maintenance of a channel with a minimum depth of } \\
11.3 \mathrm{~m} \text { below low-water line which may be affected by } \\
\text { reductions of water levels and flows in St. Lawrence River } \\
\text { arising from lower precipitation and lower Great Lakes } \\
\text { levels. }\end{array}$ \\
\hline Little Bow Reservoir & $\begin{array}{l}\text { Water supply for use in irrigation, municipal water supply } \\
\text { and water based recreation as affected by changes to } \\
\text { precipitation regime and demand from use of } \\
\text { evapotranspiration. }\end{array}$ \\
\hline Decommissioning of Quirke and Panel Mines & $\begin{array}{l}\text { Permanent containment of tailing ponds requiring } \\
\text { adequate supply as affected by extremes in precipitation, } \\
\text { both excessive amounts giving rise to floods and } \\
\text { insufficient amounts giving rise to droughts. }\end{array}$ \\
\hline
\end{tabular}

Source: Adapted from Lee (2001)

The Confederation Bridge between New Brunswick and Prince Edward applied the existing operational guidelines on how climate change considerations can be included in the EIA process (Bell et al., 2002). This project considered the construction of a $27 \mathrm{~km}$ long bridge structure. This bridge was 
designed to permit the passage of vessels and stands approximately $40 \mathrm{~m}$ above sea level at the side spans and $60 \mathrm{~m}$ above sea level over the main navigational channel. The goal was to develop the structural requirements considering a design life of 100 years over which the bridge could withstand all probable stresses, including from ice and wind. The EIA process considered not just the effects of the bridge on the environment but also the effects of the environment on the bridge. This took into account the effects of environmental conditions in the coming 100 years due to the anticipated design life of the bridge. In response to this requirement, design and construction of structures incorporated safety factors to minimize risks associated with climate change. It is important to note that the EIA process had access to a large body of environmental information, including resource management data and information generated by specific investigations conducted over the previous 20 years. At the same time, studies were undertaken to consider the environmental conditions over a 100 year time frame (Bell et al., 2002).

This assessment resulted in the bridge being built higher than currently required to accommodate projections of sea level rise. Additionally, a monitoring program was established to provide early warning of unanticipated changes in order to allow adjustments. This included monitoring of water temperatures, currents, coastal erosion, coastal sediment transport, and ice conditions affecting the bridge (Bell et al., 2002). This case provides an illustration of a mechanism for incorporating monitoring of climate variables through conditions of approval.

Another project in Canada involved the decommissioning of the Quirke and Panel Uranium Mines at Elliot Lake. This included, among other activities, the construction of permanent containment ponds for the radioactive tailings. The radioactive tailings needed to remain permanently flooded in order to prevent the generation of acid that would result from exposure to air. The design of the tailing ponds consisted of a series of dams and dikes to construct a terraced series of water-covered containment cells. Lee (2001) summarized the consideration of climate change considerations in the EIA for this project as follows: "The proponent primarily took climate change into account through the use of drought and flood models by allowing for the possibility of decreasing mean precipitation and increasing mean evaporation by up to $10 \%$. In developing models, the proponent analyzed the databases for evaporation and precipitation, concluding that there was no monotonic trend for both precipitation and evaporation. Hence, they may have made an underlying assumption that the climate is not changing and $10 \%$ was a reasonable additional measure of safety. These models were based on climate records of 55 years and 18 years, respectively. Further, the proponent believed that long-term monitoring was unnecessary to assess and validate whether climate change was occurring".

In a preliminary review of the Environmental Impact Statement Submission by the proponent, Environment Canada noted shortcomings in terms of comparability of data, as well as with regard to the assumptions about evapotranspiration, wind and atmospheric stability. In particular, it pointed to a study that projected evapotranspiration for the Lake Huron Basin to be more than $20 \%$ higher in 2050 than historic levels. Further, it noted that there was a need to incorporate the best estimates of the effects of climate change on key climate parameters. The EIA Panel subsequently directed the proponent to conduct appropriate risk assessments including consideration of a catastrophic or accidental event based on the current climate and geology as well as on the best estimates of long-term climate changes and their associated uncertainties. The decommissioned waste facilities are required to perform their protective functions for millennia, during which time there will be changes to the environmental conditions within which they operate (Lee, 2001). The EIA Panel noted that the two potential problems most frequently mentioned were either flooding caused by excessive precipitation events, or the evaporation and subsequent loss of water cover during prolonged droughts. It concluded that the tailings, with suitable arrangements, could be kept permanently saturated either under a water cover or under a dry cover if a sufficient, reliable supply of water was permanently available. Properly designed and constructed, such a system would be both robust and flexible. It could operate effectively over a considerable range of climatic and other conditions, and be modified to adapt to changing conditions or requirements. The Panel also 
noted that potential climate change makes necessary the capability to keep local weather records in Elliot Lake. It further urged the Atomic Energy Control Board to consider explicitly operating, monitoring and maintenance needs to determine whether they should be incorporated in the approved licensing procedures and plans.

Based on the evaluation of all six projects mentioned above, Lee (2001) concluded that the EIA process in these projects used historical climate data for normals, climate variability and extremes in at least some aspects of their planning. Some projects considered the use of historical data as an adequate indication of the future; others used the range of historical natural variability to discuss climate change. Nevertheless, Lee also states that observational records were inadequately examined in many projects. At the same time, the difficulties of using climate change scenarios are noted. One recommendation that is made is to improve the scale of resolution of climate change scenarios as much as possible. The report also states that uncertainty could be addressed with a range of probable futures. He also notes that: "Climate change science is unlikely ever to be able to present climate information in the same manner as historical data to which the EA community is accustomed. This is something that the EA community will have to accept. Climate change scientists on the other hand should start a dialogue with the EA community to determine how their research agenda can accommodate the EA community" (Lee, 2001).

More recently, Byer and Yeomas (2007) reviewed several recent EIA reports in Canada and concluded that climate change and the uncertainties about climate change have not been adequately addressed in most EIA; and they found inconsistencies between similar types of projects. This may be explained by i) the difficulties that EIA practitioners experience to address climate change information and its uncertainties; ii) the low accessibility for EIA practitioners to user-friendly climate change information. These issues are the result of the novelty of this practice area and are likely to be better addressed once practitioners have developed skills and experience to address climate change adaptation as part of an EIA. Meanwhile, another recent report from Canada states that some stakeholders in the private sector have suggested that information gaps such as projections of climate change and changes in other environmental conditions pose challenges to meeting the considerations of climate change in EIA as a legal requirement (National Round Table on the Environment and the Economy, 2009).

\subsubsection{Australia}

A number of examples of implementing climate change adaptation in EIA can also be found in Australia. Although there is not a national framework for the consideration of climate change adaptation in EIA, planning authorities in some Australian states and territories such as the Australian Capital Territory (ACT) and New South Wales (NSW) require a climate change risk assessment be undertaken. The list in Table 2 shows some recent projects undertaken in Australia, which required an EIA that included climate change risks assessment. This list should not be considered as exhaustive. 
Table 2. Example of Australian projects requiring consideration of climate change in an EIA

\begin{tabular}{|c|c|c|}
\hline Project name & Project type & State/Territory \\
\hline $\begin{array}{l}\text { East Lakes 132kV Substation, Sub } \\
\text { transmission Line and Cable Routes }\end{array}$ & Electricity transmission & ACT \\
\hline Mulligan Flats Road Upgrade & Road & ACT \\
\hline $\begin{array}{l}\text { Mount Franklin Road, Cotter Hut Road and } \\
\text { Smokers Trail, Namadgi National Park }\end{array}$ & Road & ACT \\
\hline Murrumbidgee to Googong Water Transfer & Water pipeline & ACT/NSW \\
\hline Clarie Hermes Drive Extension & Road & ACT \\
\hline Kings Highway Southern Deviation & Road & $\mathrm{ACT}$ \\
\hline Armidale Landfill & Landfill & NSW \\
\hline South West Rocks Aquaculture & Aquaculture & NSW \\
\hline $\begin{array}{l}\text { Boollwarroo Parade, Shell Cove - } \\
\text { Shellharbour / Shell Cove Boat Harbour } \\
\text { Precinct, Shell Cove }\end{array}$ & Residential Development & NSW \\
\hline $\begin{array}{l}\text { Barangaroo (formerly East Darling Harbour) - } \\
\text { Sydney }\end{array}$ & Residential Development & NSW \\
\hline DPI Land at Bloomfield - Orange & $\begin{array}{l}\text { Residential and Retail Space } \\
\text { Development }\end{array}$ & NSW \\
\hline
\end{tabular}

Source: ACTPLA (2010), NSW Department of Planning (2010)

The East Lakes electrical infrastructure project is located on the banks of Lake Burley Griffin next to the Jerrabomberra wetlands in the ACT. It triggered an EIA and, as part of the scoping requirement, a climate change risk assessment. Flood studies in the area indicate that the substation site (E4) is within a probable maximum precipitation design flood. Assuming use of natural contours, climate change modelling suggested that by 2030 there will be a moderate risk of E4 being flooded, due to an increase in extreme daily rainfall events, and the intensity and frequency of storms. This could result in a less reliable electricity supply without mitigation and could increase the costs associated with repairs and infrastructure replacement. The likely risk under a 2070 low scenario is also moderate, but in a 2070 high scenario, the modelling shows a high risk of flooding. To ensure integrity of the network during peak flood events the EIA recommends that all electrical equipment in E4 should be positioned approximately $2 \mathrm{~m}$ above the probable maximum flood level to avoid potential future flood risks. The decline in stability due to ground movements and impact on foundation was considered low. The effects of climate change will also include extended dry periods, resulting in increased dust build-up and potential transformer failures. The design of structures includes a significant safety margin to minimise the risk of catastrophic failure and operational procedures include maintenance and reacting to spills and other major failure events. An additional effect will be the increased load to the system due to increased temperatures and more frequent heat waves requiring air conditioners and other power demands. However, the current project at East Lake will assist in servicing the increased demand with sustained reliability (AECOM/Purdon Associates, 2009).

The Mulligans Flat Road connects the northern part of the ACT with NSW. It was decided to upgrade the single lane unsealed road to a two lanes sealed road. This proposed upgrade resulted in the preparation of an EIA. Three elements of the road upgrade were considered sensitive to climate change: the road pavement (with a possible degradation due to higher air temperature), the road foundations and the floodways and flood ponds associated with the road upgrade. The impacts linked to increase in heavy rainfall events and likelihood of flooding were identified as key risks potentially exacerbated by climate change. Both the pavement and the drainage/floodway systems have been designed based on the latest available climate observations (1939-2009). It would be recommended to review the rainfall standard for 
the floodway and the temperature standards for the pavement when the road will be refurbished. All floodways have been designed to withstand a 1 in 100 year event. In some floodways, an extra margin of up to 300 millimetres (corresponding to $11 \%$ of the 1 in 100 year's flood height level) has been added in the design, as shown in Figure 2.

Figure 2. Floodway with 1 in 100 years flood level and $300 \mathrm{~mm}$ freeboard

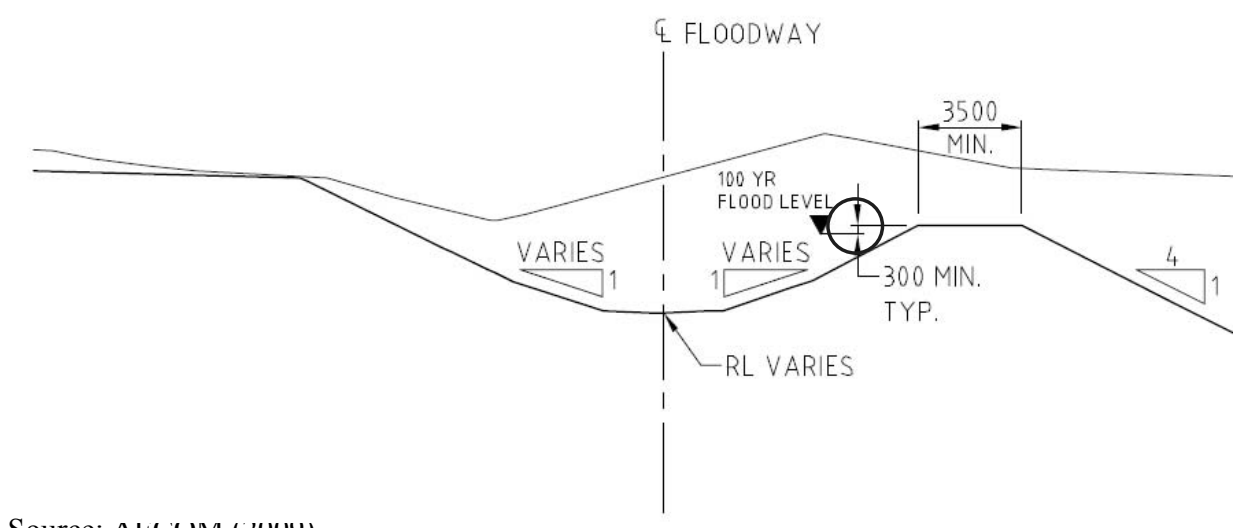

Source: AeL UIM (ZUUY)

Mount Franklin Road, Cotter Hut Road and Smokers Trail are located in the Namadgi National Park in the ACT. The upgrade of some sections of these three fire trails triggered an EIA for which climate change issues were assessed. The project justification highlights that this upgrade will contribute to reduce the climate change vulnerability of the Canberra region with regards to bushfire (wild fire) hazard. Climate change impacts on local biodiversity are mentioned in the fauna and flora assessment section as one of the threatening processes on the species and ecological communities potentially impacted by the road and trail upgrade. Alpine Sphagnum Bogs and Associated Fens and the Northern Corroboree Frog (Pseudophryne pengilleyi) are listed under the EPBC Act and are respectively considered as "endangered" and "vulnerable" under this legislation. Both this ecological community and this frog species are likely to be negatively impacted by climate change. The environmental design of the project took this specific vulnerability into account (Aurecon, 2009).

The Murrumbidgee to Googong Water Transfer project is part of the ACT Government Water Security Program and aims to improve security to the ACT's water supply. It involves pumping water from the Murrumbidgee River (ACT) and transferring it via a pipeline to the Googong Reservoir via Burra Creek (NSW). The Googong Reservoir supplies water treated to drinking quality standards. Climate change risks have been assessed as part of the EIS, with climate change mentioned in the project justification, as the proposed development would improve significantly the water supply for the ACT. Water scarcity has been identified as one of key risks from climate change for this Australian region. The climate change risk assessment involved a workshop and the following activities:

- $\quad$ Define the scope of the risk assessment - i.e. project boundaries;

- Set clear objectives for the risk assessment - a 'first pass climate change risk and adaptation appraisal';

- $\quad$ Confirm time horizons - e.g. 2030 and 2070;

- Select and agree on data sources (CSIRO, 2007); 
- Agree and select relevant climate change variables for the project - preliminary and secondary impacts (temperature, rainfall, extreme events, hail, bushfire, evaporation);

- Identify participants in risk assessment - ActewAGL Murrumbidgee to Googong designers, operators and asset owners; and

- Select elements at risk in the project.

Changes in air temperature, rainfall, heat waves, hail and bushfire risk and how they impact the construction, operation and maintenance of the water pipeline were considered. Adaptation measures such as use of concrete poles instead of wooden poles, use of submersible pumps, design for higher flood levels for creek crossing and intake and design of the pumping station roof for higher wind loading were recommended for implementation. It was also suggested to put a monitoring program in place to assess progress on major risks identified (Actew Corporation, 2009).

The Armidale landfill project is located in the New England Tablelands in NSW. Armidale is a significant regional centre and the landfill is expected to fulfil the waste disposal needs for this region. The initial EIA was submitted without consideration of climate change. The NSW regulatory authorities requested that a climate change risk assessment be integrated in the EIA with special attention to changes in rainfall pattern and surface runoff. After screening for climate change considerations, the leachate pond and the sedimentation were identified as the key elements of the project presenting sensitivity to climate change. A water balance model was used to determine the size of the leachate pond. An increase in rainfall intensity could potentially result in overtopping of the sedimentation basin and leachate pond due to a higher volume of rainfall. On the other hand, a decrease in rainfall would mean that the leachate pond and sedimentation have been designed for a high volume of precipitation that is unlikely to occur in the future (resulting in higher construction, operation and maintenance costs for the landfill owner).

The water balance model was developed using 10 years of average daily rainfall data for Armidale between 1982 and 1991. This period was considered representative of the overall average annual rainfall and included a range of both wet and dry years (for instance $697 \mathrm{~mm} /$ year for dry years, $745 \mathrm{~mm} /$ year for an average year and $807 \mathrm{~mm} /$ year for wet years). Seasonal rainfall projection for 2030 and 2070 are currently being used as input data for the water balance model to evaluate the corresponding change in the sedimentation basin and leachate pond design. Rainfall projections range from a $10 \%$ decrease for spring rainfall by 2030 to a $20 \%$ increase for autumn by 2030 while projections for 2070 show slight increase or little changes across all seasons (AECOM, 2010). This range of climate projections, not only in magnitude but also in direction of changes, is proving challenging to factor in the water balance model and design. Finally, despite the requirement by NSW regulatory authorities to consider changes in runoff conditions, it was not possible to assess potential impacts linked to this variable due to the lack of relevant local data. This example highlights the difficulty to source climate data at the project spatial scale. 
Box 5. Using climate data and risk framework for EIA: Armidale landfill, Australia

During the drafting of climate change risk assessment as part of an EIA described above, four steps were considered. This box details these four steps and presents some of the results of each step:

\section{Step 1 - Screening for climate sensitivity}

- Review project brief to identify all project aspects including design elements.

- Broad level discussion with key designers and project manager to identify project aspects which are climate sensitive.

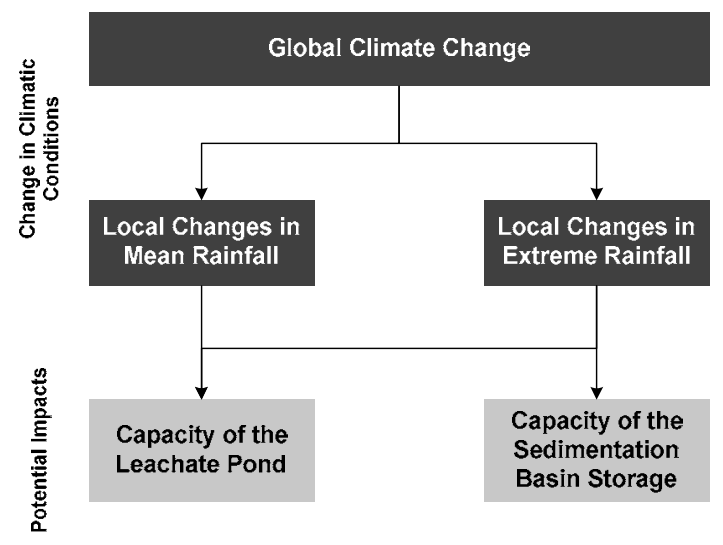

\section{Step 2 - Sourcing climate observations and projections}

- Source data set from the Bureau of Meteorology to characterise the average climate in the vicinity of the proposed development and identifying recent observed trends in terms of climate change.

- Liaise with CSRIO to obtain climate projections at the finest possible scale. This is usually done by providing GPS coordinates of the proposed development. CSIRO typically provides climate projections for a $1^{\circ} \times 1^{\circ}$ grid cell centred on these coordinates.

- Review published State guidelines and policies for the considered area (e.g. NSW Government 2009-Sea Level Rise Policy Statement).

Average climate for the Armidale region

ARMIDALE AIRPORT AWS

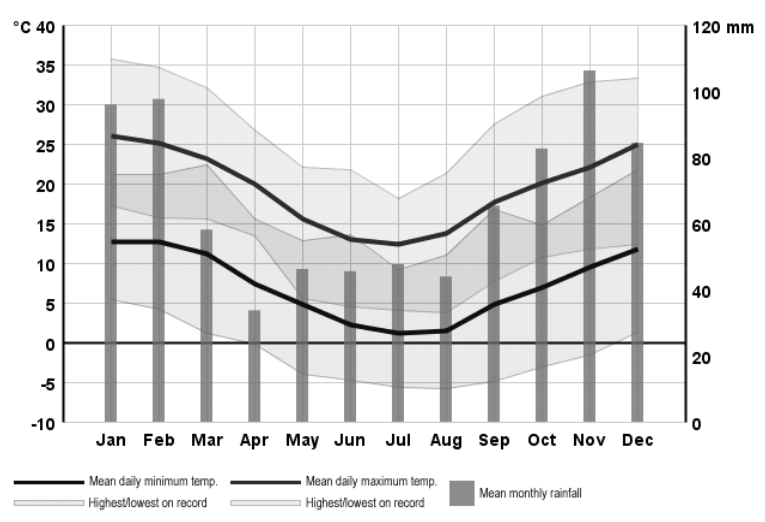

Data: BOM (2010) 


\section{(Box 5 Continued)}

Regional projections for 2050 indicate that spring and autumn mean rainfall is likely to increase by $5 \%$ to $10 \%$, summer mean rainfall to increase by $10 \%$ to $20 \%$ and winter rainfall to decrease by $10 \%$ to $20 \%$ (DECC, 2008).

\section{Extreme rainfall projections for the NSW north-east region}
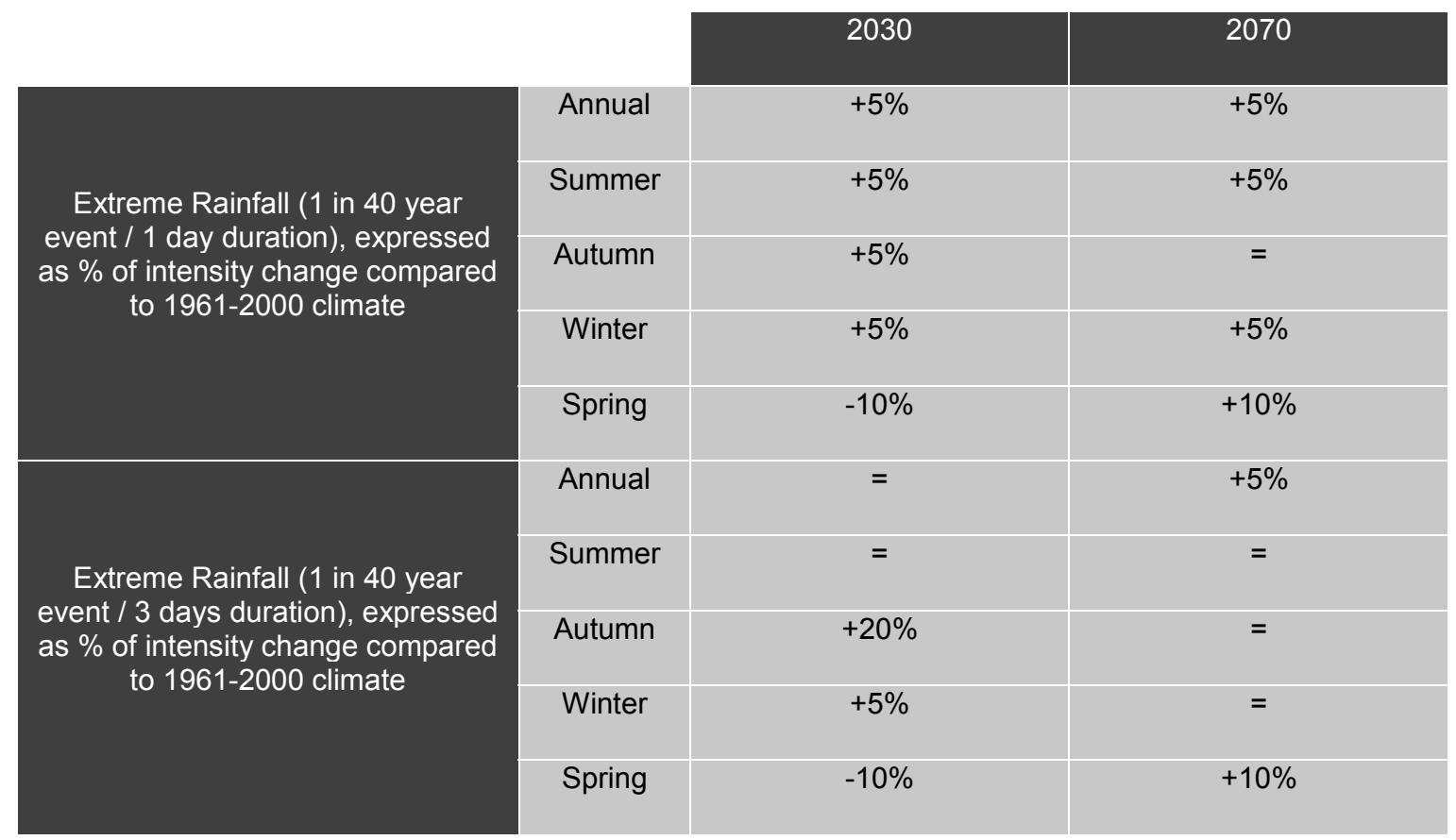

Data: CSIRO (2004)

\section{Step 3 - Prepare climate change risk and adaptation options assessment}

- Using the risk framework and the climate data determine the likelihood and consequences of the climate risks to the proposed project.

- Validate these draft findings in a working session with the key designers and project manager.

- Discuss any risk reduction measure, buffer zone, design flexibility already in place, how they address the identified climate change risks and how can they be expanded or amended to reduce these risks.

Risk matrix used for the assessment

\begin{tabular}{|c|c|c|c|c|c|}
\hline \multirow{2}{*}{ Likelihood } & \multicolumn{5}{|c|}{ Consequences } \\
\cline { 2 - 6 } & Insignificant (1) & Minor (2) & Moderate (3) & Major (4) & Catastrophic (5) \\
\hline Almost certain (5) & M (5) & M (10) & H (15) & E (20) & E (25) \\
\hline Likely (4) & L (4) & M (8) & H (12) & H (16) & E (20) \\
\hline Possible (3) & L (3) & M (6) & M (9) & H (12) & M (15) \\
\hline Unlikely (2) & L (2) & L (4) & M (6) & M (10) \\
\hline Rare (1) & L (1) & L (2) & L (3) & L (4) & M (5) \\
\hline
\end{tabular}




\section{(Box 5 Continued)}

$E=>20$ : Extreme risks demand urgent attention at the most senior level and cannot be simply accepted as a part of routine operations without executive sanction.

$\mathrm{H}=>12$ : High risks are the most severe that can be accepted as a part of routine operations without executive sanction but they will be the responsibility of the most senior operational management and reported upon at the executive level.

$M=>5$ : Medium risks can be expected to form part of routine operations but they will be explicitly assigned to relevant managers for action, maintained under review and reported upon at senior management level.

$\mathrm{L}=<5$ : Low risks will be maintained under review but it is expected that existing controls will be sufficient and no further action will be required to treat them unless they become more severe.

\section{Risk rating using the matrix}

\begin{tabular}{|c|c|c|c|c|}
\hline Risk Scenario & $\begin{array}{c}\text { Climate } \\
\text { Variable }\end{array}$ & Risk Description and Flow-on Effects & $\begin{array}{c}\text { Risk } \\
\text { Rating } \\
2030\end{array}$ & $\begin{array}{c}\text { Risk } \\
\text { Rating } \\
2070\end{array}$ \\
\hline $\begin{array}{c}\text { The leachate pond is } \\
\text { not designed to cope } \\
\text { with future rainfall } \\
\text { patterns }\end{array}$ & $\begin{array}{c}\text { Mean rainfall } \\
\text { and extreme } \\
\text { rainfall }\end{array}$ & $\begin{array}{c}\text { An increase in rainfall intensity could } \\
\text { potentially result in overtopping of the } \\
\text { leachate pond due to a higher volume of } \\
\text { rainfall. }\end{array}$ & Medium & Medium \\
\hline
\end{tabular}

\section{Step 4 - Peer Review}

- Key findings from the previous steps are reviewed by an internal but independent practitioner with climate change risk assessment experience.

Source: AECOM (2010)

\subsection{Summary assessment}

Based on the discussion in the preceding sections Figure 3 provides the overall picture of the evolution of adaptation to climate change in EIA. It lists (i) all countries and jurisdictions that this study could identify, which have stated in a relevant planning document the need to incorporate climate change impacts and adaptation considerations into their EIA processes; (ii) countries that actually have adopted a legal framework to respond to this request and/or developed operational guidelines; and (iii) those that have implemented climate proofing through EIA on their projects. 
Figure 3. Evolution of EIA and adaptation

Level 1 - Intention
Developed Countries
Canada
Spain
European Union
Developing Countries
Bangladesh
Dominica
Kiribati
Saint Lucia
Samoa
Solomon Islands
Caribbean Community
Multilateral Organisations
Asian Development Bank
Inter-American Development Bank
World Bank

Level 2 - Guidance
Developed Countries
Australia
Canada
Netherlands
Developing Countries
Grenada
Kiribati
Trinidad and Tobago
Caribbean Community

As Figure 3 shows, there is a strong gap between the desire to incorporate adaptation to climate change in EIA and putting it in practice. The overall integration of climate change adaptation in EIA processes remains at an early stage in both developed and developing countries. While there are several countries that have expressed their intention to use EIA as a tool to adapt projects to climate change, only a few have taken steps to include formal legal frameworks and operational guidelines to include adaptation to climate change into their EIA process.

The availability of, and uncertainties associated with, climate change projections at the project scale are clearly a key bottleneck. Projects can be sensitive to a broad set of climate related variables that range from increases in temperature to changes in rainfall, stream flow, permafrost thickness, and wind intensity. Climate models, however, can project certain variables better than others. For example, temperature increase is easier to project than sea level rise or changes in rainfall, which in turn are easier to project than changes in wind intensity (Agrawala and van Aalst, 2005). Projects are also typically more sensitive to changes in climate extremes compared to changes in average conditions. However, projections of changes in climate extremes are much more difficult and uncertain compared to projections of changes in mean trends. Further, local scale climate projections that are relevant for project level decision-making also tend to be more uncertain than climate projections over a larger spatial area (Agrawala and van Aalst, 2005). Nuances like these are often insufficiently understood by, and/or inadequately communicated to, project developers and those charged with environmental assessment.

Another factor that might explain the gap between the desire to incorporate climate change adaptation in EIA and putting it into practice is the emergence of alternative "stand-alone" tools and climate screening methods that have been developed by the climate change community which have yet to make the cross-over to mechanisms such as EIA. Some climate change adaptation experts also question the suitability of EIA for promoting climate risk management. Klein et al. (2007) argue that challenges persist in ensuring the quality, relevance and independence of EIA and in implementing their recommendations. In addition, the authors argue that EIA may fail to consider local perspectives which are relevant for any climate risk assessments where local experiences could be a key asset for identifying relevant indicators and adaptation options. 
ENV/WKP(2010)10

\section{Concluding Remarks}

This analysis shows that there is ample scope for employing EIA procedures as a vehicle for enhancing the resilience of projects to the impacts of climate change. A number of entry points have been identified to incorporate climate change impacts and adaptation considerations, from the strategic phase that precedes the initiation of the EIA, to the scoping, detailed assessment and implementation stages.

Several national and sub-national authorities as well as multilateral development banks have already made some progress in terms of examining the possibility of incorporating climate change impacts and adaptation measures within the context of EIA modalities. Several countries and organisations have signalled their intent in planning documents and strategies. This includes some developed countries but also, most notably, several SIDS from the Caribbean and the Pacific. At the same time, very few countries have actually developed operational guidance or adjusted existing policy frameworks to achieve the objective of using EIA to climate proof projects. Finally, in terms of actual implementation of EIA projects that incorporate consideration of climate change impacts, this assessment could only find examples in three countries - Australia, Canada, and the Netherlands.

While these examples clearly show that EIA can be used as a vehicle for adaptation, they also raise a number of issues. In several projects the climate risk component of the EIA only relied on historical climate data which was not a reliable predictor for future climate. Climate change impact assessment methodologies in some projects have also been inconsistently applied in some cases. Conversely, there are several examples - most notably in Australia - of systematic consideration of future climate scenarios within the EIA, which have also led to the adaptation of the project design. This however requires the availability of detailed information on the historical climate, as well as fairly specific scenarios of future climate for the project location. In many jurisdictions such a commonly available and accepted information base may not be available. Greater investment in generating reliable climate change projections at a local level would not only facilitate the integration of climate change adaptation within EIA but would also facilitate the implementation of a variety of other adaptation measures.

Another important issue relates to the uncertainties in projections of future climate. A key point here is that projections of various aspects of climate change have differing degrees of associated uncertainties. Larger scale climate projections typically have lower uncertainty than those specific to a particular location. Quite often, the variables that matter most for project design, such as rainfall, flooding and other weather extremes, are also associated with greater uncertainty. There may therefore be a risk of unnecessary or even counterproductive investments in altering project design if these uncertainties are not adequately considered. In such cases a flexible approach that takes into account the associated scientific uncertainties may be more warranted. While it might be naive to call for a significant reduction in scientific uncertainty within climate model projections in the near future, more could be done to facilitate its transparent communication to project proponents and those with tasked with oversight of proper consideration of climate change scenarios within EIA.

Finally, at this stage it is difficult to answer conclusively whether consideration of climate change impacts should become a legal requirement within EIA. There is clearly promise in terms of using EIA as a vehicle to further promote climate proofing at the project level, but national governments and development agencies are still at an early stage in terms of how to operationalise this. Innovative approaches are currently being developed and tested, but it is important that they retain a certain degree of flexibility in implementation as better and more detailed climate change information becomes available. There is also a concomitant need to make substantial and long-term investments in the provision of climate change information, as well as establishing good communication mechanisms between the scientific community and practitioners so that climate change information could be appropriately incorporated within EIA. 


\section{REFERENCES}

Actew Corporation (2009), Murrumbidgee to Googong Water Transfer: Environmental Impact Statement (ACT) and Environmental Assessment (NSW) - Climate Change Risk Assessment, Canberra, Australia.

ACTPLA (2010), Draft Environmental Impact Statements, Canberra, Australia, http://www.actpla.act.gov.au/topics/your_say/comment/draft_eis, accessed 05 March 2010.

ADB (2005), Climate Proofing: A Risk-based Approach to Adaptation, Pacific Studies Series, Asian Development Bank, Philippines.

AECOM (2009), Mulligan Flats Road Upgrade: Draft Environmental Impact Statement, Canberra, Australia.

AECOM (2010), Armidale Landfill: Draft Environmental Impact Assessment, Sydney, Australia.

AECOM/Purdon Associates (2009), East Lake Electrical Infrastructure: Draft Environmental Impact Statement, Vol. 1, Canberra, Australia.

Agrawala, S. and M. van Aalst (2005), "Bridging the gap between climate change and development", Bridge Over Troubled Waters: Linking Climate Change and Development, OECD, Paris, pp. 133146. doi: $10.1787 / 9789264012769$-en

Aurecon (2009), Mount Franklin Road, Cotter Hut Road and Smokers Trail, Namadgi National Park: Draft Environmental Impact Statement, Canberra, Australia.

Bell, A., N. Collins, C. Ells, G. de Romily, A. Rossiter and R. Young (2002), Evaluation of the ClimAdapt Guide to Incorporating Climate Change into the Environmental Impact Assessment Process, Research and Development Monograph Series, ClimAdapt - Nova Scotia's Climate Change Adaptation Initiative, Canada.

BOM (2010), Armidale Airport AWS, Bureau of Meteorology, Commonwealth Government, http://www.bom.gov.au/jsp/ncc/cdio/weatherData/av?p_nccObsCode $=136 \& p \_d i s p l a y \_t y p e=d a i l y D$ ataFile\&p_startYear $=2010 \& p \_s t n \_n u m=0562381$, accessed 23 March 2010.

Byer, P.H. and J.S. Yeomas (2007), "Methods for addressing climate change uncertainties in project environmental impact assessments", Impact Assessment and Project Appraisal, Vol. 25, No. 2, pp. 85-99.

Canadian Environmental Assessment Agency (2003), Incorporating Climate Change Considerations in Environmental Assessment: General Guidance for Practitioners, Federal-Provincial-Territorial Committee on Climate Change and Environmental Assessment.

Canadian Environmental Assessment Agency (2009), Basics of Environmental Assessment, http://www.ceaa-acee.gc.ca, accessed 01 November 2009. 
CARICOM (2004), Guide to the Integration of Climate Change Adaptation into the Environmental Impact Assessment (EIA) Process, CARICOM and SPREP.

CDB and CARICOM (2004), Sourcebook on the Integration of Natural Hazards into the Environmental Impact Assessment (EIA) Process, Caribbean Development Bank, Barbados.

CSIRO (2004), Climate Change in New South Wales: Part 2 - Projected changes in extremes, Consultancy report for the NSW Greenhouse Office, $79 \mathrm{pp}$.

CSIRO (2007), Climate Change in Australia: Technical Report 2007, CSIRO and Australian Bureau of Meteorology, $148 \mathrm{pp}$.

DECC (2008), Summary of Climate Change Impacts New England/North West NSW Region, 4 pp.

Draaijers, G. and A. van der Velden (2009), The NCEA's recommendations on Climate Change in Environmental Assessment, Netherlands Commission for Environmental Assessment.

Dutch Ministry of Transport, Public Works and Water Management (2006), Spatial Plan Key Decision 'Room for the River', Official Brochure.

EuropeAid (2009), Guidelines on the Integration of Environment and Climate Change in Development Cooperation, Guidelines No. 4, Tools and Methods Series, European Union, Luxembourg.

European Commission (2009a), Study Concerning the Report on the Application and Effectiveness of the EIA: Final Report, European Commission Directive DG ENV, Brussels, Belgium.

European Commission (2009b), Adapting to Climate Change: Towards a European Framework for Action, White Paper, Brussels, Belgium.

Government of Kiribati (2007), Republic of Kiribati: National Adaptation Programme of Actions, Ministry of Environment, Land, and Agricultural Development, Tarawa, Kiribati.

Government of Saint Lucia (2001), Saint Lucia's initial national communication on climate change: In response to its commitments under the United Nations Framework Convention on Climate Change, Ministry of Planning, Development, Environment and Housing.

Government of Samoa (1999), First national communication to the UNFCCC, Department of Lands, Survey and Environment, Apia, Samoa.

Government of Samoa (2005), National Adaptation Programme of Actions: Samoa, Ministry of Natural Resources, Environment and Meteorology.

Government of Solomon Islands (2008), Solomon Islands: National Adaptation Programme of Actions, Ministry of Environment, Conservation and Meteorology.

Government of the Commonwealth of Dominica (2001), Initial National Communication of the Commonwealth of Dominica under the United Nations Framework Convention on Climate Change, Environmental Coordinating Unit (ECU), Ministry of Agriculture and the Environment, Roseau, Dominica.

Government of the Cook Islands (2000), Initial National Communication under the United Nations Framework Convention on Climate Change, PICCAP Cook Islands. 
Government of the People's Republic of Bangladesh (2005a), National Adaptation Programme of Action, Ministry of Environment and Forest.

Government of the People's Republic of Bangladesh (2005b), National Water Management Plan Project: Guidelines for Environmental Assessment of Water Management (Flood Control, Drainage and Irrigation) Projects, Ministry of Water Resources.

Government of the Republic of Vanuatu (2007), Republic of Vanuatu: National Adaptation Programme of Actions, National Advisory Committee on Climate Change.

Glasson, J., R. Therivel and A. Chadwick (2005), Introduction to Environmental Impact Assessment, Third edition, Routledge, New York, USA.

IADB (2008), Disaster Risk Management Policy Guidelines, prepared by C. Rogers, T. Hori and R. Gaggero.

IAIA (1999), Principles of Environmental Impact Assessment: Best Practice, International Association of Impact Assessment and Institute of Environmental Assessment.

Klein R., S. Eriksen, L. Næss, A. Hammill, C. Robledo and K. O’Brien (2007), "Portfolio screening to support the mainstreaming of adaptation to climate change into development". Climatic Change, Vol. 84, No.1, pp. 23-44.

Lee, R.J. (2001), Climate Change and Environmental Assessment: Part 1- Review of Climate Change Considerations in Selected Past Environmental Assessments, Report to the Canadian Environmental Assessment Agency, Research and Development Monograph Series.

Lemmen, D.S., F.J. Warren, J. Lacroix, and E. Busch [Eds.] (2008), From Impacts to Adaptation: Canada in a Changing Climate 2007, Government of Canada, Ottawa, Canada, 448 pp.

National Round Table on the Environment and the Economy (2009), True North: Adapting Infrastructure to Climate Change in Northern Canada, NRTEE, Ottawa, Canada.

New South Wales Government (2009), Sea Level Rise Policy Statement, Department of Environment, Climate Change and Water NSW, Sydney, Australia.

NSW Department of Planning (2010), Major Project Assessment, http://majorprojects.planning.nsw.gov.au/page/project-sectors/, accessed 16 March 2010.

OECD (2008), Strategic Environmental Assessment and Adaptation to Climate Change, Endorsed by members of the DAC Network on Environment and Development Co-operation (ENVIRONET) at their $8^{\text {th }}$ Meeting on 30 October 2008, OECD, Paris.

OECD (2009), Integrating Climate Change Adaptation into Development Co-operation: Policy Guidance, OECD Publishing. doi: 10.1787/9789264054950-en

Oficina Española de Cambio Climático (2006), Plan Nacional de Adaptación al Cambio Climático, Ministerio de Medio Ambiente.

Oficina Española de Cambio Climático (2009), Plan Nacional de Adaptación al Cambio Climático: Segundo Programa de Trabajo, Ministerio de Medio Ambiente. 
Petts, J. (1999), Handbook of environmental impact assessment, Vol. 1, Blackwell Science, Oxford, UK.

Rudock, K. (2009), Factoring climate change and sea level rise into planning and infrastructure decisions, New South Wales, Australia, http://www.edo.org.au/edonsw/site/papers.php.

Sadler, B. and R. Verheem (1996), Strategic environmental assessment: key issues emerging from recent practice, Ministry of Housing, Spatial Planning and the Environment, Hague, Netherlands.

Verheem, R. and M. Laeven (2009), "SEA for flood protection in the Netherlands: A Case Study".

World Bank (1999), "Global and Cross: Sectoral Issues in Environmental Review", Environmental Assessment Sourcebook 1999, Chapter 2, Washington DC, USA.

World Bank (2009), Reducing the Risk of Disasters and Climate Variability in the Pacific Islands Republic of Kiribati Country Assessment, Washington DC, USA. 